\title{
Measuring and Reducing the Impact of Corruption in Infrastructure
}

\author{
Charles Kenny ${ }^{1}$
}

\begin{abstract}
This paper examines what we can say about the extent and impact of corruption in infrastructure in developing countries using existing evidence. It looks at different approaches to estimating the extent of corruption and reports on the results of such studies. It suggests that there is considerable evidence that most existing perceptions measures appear to be very weak proxies for the actual extent of corruption in the infrastructure sector, largely (but inaccurately) measuring petty rather than grand corruption. Existing survey evidence is more reliable, but limited in extent and still subject to sufficient uncertainty that it should not be used as a tool for differentiating countries in terms of access to infrastructure finance or appropriate policy models. The paper discusses evidence for the relative costs of corruption impacts and suggests that a focus on bribe payments as the indicator of the costs of corruption in infrastructure may be misplaced. It draws some conclusions regarding priorities for infrastructure anticorruption research and activities in projects, in particular regarding disaggregated and actionable indicators of weak governance and corruption.
\end{abstract}

World Bank Policy Research Working Paper 4099, December 2006

The Policy Research Working Paper Series disseminates the findings of work in progress to encourage the exchange of ideas about development issues. An objective of the series is to get the findings out quickly, even if the presentations are less than fully polished. The papers carry the names of the authors and should be cited accordingly. The findings, interpretations, and conclusions expressed in this paper are entirely those of the authors. They do not necessarily represent the view of the World Bank, its Executive Directors, or the countries they represent. Policy Research Working Papers are available online at http://econ.worldbank.org.

\footnotetext{
${ }^{1}$ Senior Economist, World Bank. Thanks to Antonio Estache, Jonathan Halpern, Laszlo Lovei, Gregory Kisunko, Todd Moss, Tina Soreide and Richard Messick for comments, and in particular Jim Anderson both for detailed comments and for pointing out a significant error in an earlier draft.
} 


\section{Summary}

This paper examines what we can say about the extent and impact of corruption in infrastructure in developing countries using existing evidence. A low-end estimate suggests that the financial costs of corruption in infrastructure investment and maintenance alone in developing countries might equal $\$ 18 \mathrm{bn}$ a year. There is considerable evidence of widespread petty corruption in the area of infrastructure connections as well as larger-scale corruption to gain construction contracts and licenses and even to change regulatory and policy practices. For example, perhaps 25 percent of electricity production is lost to illegal connections in India, as much as 24 percent of funds destined for road construction in a project in Indonesia 'went missing' and in the region of seven percent of government contract values are paid in bribes according to survey respondents in Eastern Europe and Central Asia.

At the same time many of our existing measures appear to be very weak proxies for the actual extent of corruption, and in particular grand corruption, in infrastructure. This applies especially to perceptions-based evidence. At the cross-country level, Transparency International's Corruption Perceptions Index (CPI) appears to be a lagging, rather than leading indicator of corruption scandals. In Indonesia, perceptions of corruption in a road project were weakly related to levels of corruption measured by physical and financial audit. They were also systematically biased, with higher perceived, and lower audited, levels of corruption in ethnically diverse communities. Overall, perceptions indicators are weakly correlated with available survey evidence regarding corruption in construction and utilities, and weakly correlated with infrastructure outcomes.

Survey responses provide considerably more accurate measures of both petty and grand corruption. In Eastern Europe and Central Asia, a large scale survey suggests that levels of corruption are different in construction firms than in other firms across countries, but that the nature of those differences varies by country. In turn this suggests that even accurate general indicators of corruption at the macro level may ill-reflect sectoral realities.

Even with large surveys, noise remains. The survey results from Eastern Europe and Central Asia allows us to make two different estimates of the percentage of company revenues paid in bribes for contracts based on survey responses. These two different estimates are correlated, but with some considerable error (see Figure 2). Again, looking at construction company responses about the level of corruption in construction contracting in their country suggests that answers do not reflect a strong common understanding of sectoral corruption. The survey data allows us to say only a limited amount with confidence about variation across countries in levels of corruption in the construction industry (see Figure Four) and it does not provide sufficient accuracy to provide an 'actionable indicator'. (It should be noted that this was not an intended aim of the survey designers). Furthermore, existing surveys do not and probably could not capture levels of grand corruption in infrastructure firms themselves. 
Evidence for the relative costs of corruption impacts suggests that a sole focus on bribe payments as the indicator of the costs of corruption in infrastructure is misplaced. Bribes that are paid in order to win contracts for well-selected projects that are subsequently well-constructed are less damaging than corruption which skews spending priorities or lowers construction standards. In Indonesia, one estimate is that each dollar stolen from road construction reduces economic benefits from the road by $\$ 3.41$. Ten percent additional project costs due to corrupt payments cannot account for the negligible macroeconomic returns to public investment in Africa, but expenditure diversion and poor construction related in part to corruption might.

Such findings suggest priorities for infrastructure anti-corruption research and activities in projects. Evidence on the extent of perceived bribery is only to some degree related to actual levels of bribe payments, and the level of bribe payments are a weak proxy for the development impact of corruption. A focus on inputs and outputs might provide better evidence of weak governance and high corruption in infrastructure, and in particular on the development impact of these problems. Such a focus would involve an evaluation of budgeting priorities and project selection procedures as well as the quality of construction of selected projects at the sectoral level. There remains an important place for focused, well-designed, large surveys to evaluate modes and levels of corruption in a particular environments, and potential policy responses. There also remains a place for improved procurement and detection procedures at the project level. But perhaps the most efficient tools for measuring and reducing the development impact of corruption at the sectoral level will have a broad governance focus. 


\section{Introduction}

Estimates regarding the cost of corruption in infrastructure suggest that 5 to 20 percent of construction costs are being lost to bribe payments, and as much as 20 to 30 percent of electricity is being stolen by consumers in collusion with staff (Gulati and Rao, 2006). Assuming that 5 percent of investment and maintenance costs in infrastructure are lost to corruption, the financial burden alone may add up to about $\$ 18$ billion a year in developing countries. ${ }^{2}$

This paper examines what we can say about the extent and impact of corruption in infrastructure in developing countries using existing evidence. It discusses both petty corruption (here taken to include 'speed payments' and other small bribes to obtain everyday services) and grand corruption (including payments to secure government contracts or major licenses, change regulations or influence the shape of laws). It looks at different approaches to estimating the extent of corruption (expert perceptions, surveys, indirect techniques) and reports on the results of such studies. It suggests that there is considerable evidence that most existing perceptions measures appear to be very weak proxies for the actual extent of corruption in the infrastructure sector, largely (but inaccurately) measuring petty rather than grand corruption. Existing survey evidence is more reliable, but limited in extent and still subject to some uncertainty. The paper discusses evidence for the relative costs of corruption impacts and suggests that a focus on bribe payments as the indicator of the costs of corruption in infrastructure may be misplaced. It draws some conclusions regarding priorities for infrastructure anticorruption research and activities in projects, in particular regarding disaggregated and actionable indicators of weak governance and corruption.

\section{Making Estimates of the Extent of Corruption in Infrastructure}

One direct way to examine the extent of corruption in a country or sector is to look at cases where it has been revealed as part of a criminal investigation. Of course, such a technique is open to a number of serious biases -for example, there will be more cases where the justice system is efficient, itself less corrupt, and is focusing on the prosecution of corruption. There will also be more cases when corrupt activities themselves are less sophisticated and easier to detect. As a result, other approaches are usually preferred if attempting to make cross-country or cross-sectoral evaluations of corruption, most commonly involving perceptions, surveys and indirect measures.

The extent of corruption is most frequently illustrated through 'corruption perception' indices. Assessments (including elements of Transparency International's Corruption Perceptions Index and the Economist Intelligence Unit rankings) ask 'experts' including senior corporate officials to rank their perceptions of the level of corruption in various countries.

\footnotetext{
${ }^{2}$ Based on investment and maintenance estimates from Fay and Yepes, 2003.
} 
Such studies rarely lead to direct dollar estimates of the extent of bribery or economic impacts, especially at the sectoral level, but they can be used as an independent variable in regression analysis to provide evidence of correlations between high perceived corruption and poor development outcomes. For example, across countries, high perceived general levels of corruption are associated with lower spending on proxies for operations and maintenance. Related to this, general perceptions of corruption have been associated with lower quality infrastructure (a lower percentage of roads in good condition and more frequent power outages for example) (Tanzi and Davoodi, 1998). We will see, however, that such results are not robust, probably reflecting the weakness of general perceptions indices in measuring the extent of corruption in infrastructure.

Survey techniques can question victims directly about the extent and level of corruption they face. At the level of petty corruption, Davis (2004) used a survey approach to estimate that the average speed payment or bribe made to get connected to piped water in India works out at $\$ 2.64$ per legal customer (see also Seligson, 2005). There are a few other firm and customer surveys that have included questions on the extent of petty corruption in infrastructure service provision, including the World Bank's business environment surveys and customer surveys in countries including India, Kenya and Peru.

At the level of grand corruption, Hobbes (2005) interviewed a small number of bidders on World Bank financed projects and suggested that "all experienced bidders know that they must offer bribes in order not just to win the contract, but also successfully implement it." He suggests that bribes are usually between 10-15 percent of the contract value, often recovered in the mark-up the bidder places on the unit prices of the procurement items. Soreide (2004) has conducted a similar, but considerably larger and more robust, survey covering international contractors based in Norway. Neither of these surveys provide infrastructure- or construction-specific data, however.

The Business Environment and Enterprise Performance Survey (BEEPS) covers over 4000 firms in 22 transition countries and was conducted for the first time in 1999-2000. The survey examines a wide range of interactions between firms and the state. ${ }^{3}$ It is the largest and most detailed cross-country survey including a wide range of questions regarding both petty and grand corruption that has been carried out. The assumption of the survey is that many of the interviewed firms will be directly involved in corruption, although (for obvious reasons) survey questions tend to revolve around the corrupt activities of 'a typical firm in your industry' rather than asking directly about corrupt activities of the respondent firm.

In 1999, the median firm reported spending one to two percent of its revenues on unofficial payments to public officials. ${ }^{4}$ At the aggregate level, across the region, the average firm suggests that it divides up its illicit payment budget as follows: 28 percent to deal with licenses, health and fire inspections, 18 percent on tax-related issues, 15 percent on securing government contracts, 12 percent for dealing with customs, 11 percent to facilitation connections to utilities and 2 percent to influence the design of legislation or

\footnotetext{
${ }^{3}$ http://info.worldbank.org/governance/beeps/

${ }^{4}$ This amongst firms which reported a percentage and did not answer "don't know."
} 
regulation. ${ }^{5}$ Such results suggest that petty bribery for infrastructure connections is somewhat of an issue in the region, and we will see that there is evidence to suggest construction industries are particularly susceptible to corruption in licensing, taxation and obtaining government contracts, in turn suggesting that infrastructure investment may be an area of concern.

The BEEPS data provides evidence on what construction firms believe is typical payoff as a percentage of the contract value made for securing a government contract in their industry (Table 1). From this we can estimate that the average perceived payoff for a government construction contract in the region is around 7 percent of the contract value (although we will see this number is uncertain). ${ }^{6}$ It is worth noting here that reports of grand corruption vary significantly across industries. The BEEPS data suggests that there is no significant correlation between cross-industry estimates of corruption and estimates of corruption given by the subset of construction industries at the national level (see Table 2). We shall see that petty corruption in infrastructure also appears to be weakly correlated with more general measures of corruption.

This suggests the importance of sector-level indicators to accurately report levels of corruption in construction and infrastructure in a particular country, however there is a paucity of cross-country data on estimates of both grand and petty corruption in infrastructure provision in particular. Looking at petty corruption, around 20 World Bank Business Environment Surveys have asked infrastructure-related questions regarding the need to pay 'gifts' in order to get a water, electricity or phone connection. With grand corruption, we have no cross-country comparable data of the extent of bribery in infrastructure firms. BEEPS did not survey infrastructure firms, for example. This reflects in part the concentrated nature of infrastructure provision which adds complexity to ensuring the anonymity of survey responses.

Beyond perceptions and survey measures, indirect estimates can use measures of losses as a proxy for the extent of corruption, potentially capturing the impact of both petty and grand corruption. In Andhra Pradesh, transmission and distribution losses were reduced from 38 to 26 percent 1999-2003 in large part through theft control and the regularization of 2.25 million unauthorized connections. This strongly suggests that corruption was significantly linked to losses in this case. In Bangladesh and Orissa, in India, around 55 percent of generated power is paid for, the rest is lost to technical and commercial losses. Of this, perhaps 15-18 percent is accounted for by 'true technical' losses, suggesting leakage due to illegal connections or underbilling accounts for as much as 30 percent of generated power (Gulati and Rao, 2006). Davis (2004) suggests that unaccounted for water accounts for 35 percent of total flows in India.

\footnotetext{
${ }^{5}$ These are unweighted country average responses.

${ }^{6}$ This assumes mid-point values for the data ranges ( $2.5 \%$ for the $0-5 \%$ range, for example) and $30 \%$ for answers of 'above 20 percent.' The lowest possible estimate (assuming $0 \%$ for the $0-5 \%$ range, and so on) is four percent, the highest (assuming 5\% for the $0-5$ range and so on, and 100\% for the 'above $20 \%$ ' answer) is ten percent.
} 
A related approach looks at levels of outputs compared to inputs in construction. Regarding grand corruption at the local level in infrastructure, Olken (2006) used measures of reported physical inputs and costs, surveyed labor inputs and costs and physical audits of outputs to determine that about 24 percent of expenditures in an Indonesian road-construction project were 'lost.' Canning and Fay (1996) report variations in the cost of construction of a kilometer of similar road that vary by as much as five to ten times. Much of this will be due to differences from factors including location, some will also be due to less efficient, more corrupt procurement practices. The ongoing World Bank effort to build a database of road construction and rehabilitation costs should help to provide benchmarks against which to estimate excess costs of construction. $^{7}$

Public expenditure tracking surveys (which track the flow of resources through layers of government bureaucracy) are a potential approach to measuring the misappropriation of government funds if combined with unit-cost and quality of service data on final outputs. They have primarily been used in social sectors to date. These surveys have found significant leakage of funds --between 30 and 76 percent of nonwage funds going to primary education in African countries, for example (Reinikka and Svensson, 2005). A similar approach will be trialed by the World Bank in the water sector this year.

There are a number of different ways to attempt to measure infrastructure corruption and its impact, then. Results to date suggest that corruption in construction and connections may both be widespread. The average firm in BEEPS survey countries in 1999 was spending perhaps $0.1-0.2$ percent of revenues for unofficial payments to get utility connections, and corrupt payments to gain government contracts in construction appear to be frequent. Although their scale is uncertain, anecdotal evidence suggests that 5 to 10 percent of contract values may be a not unreasonable estimate in some countries. Direct physical audits point to significant corruption in Indonesian roads projects adding up to as much as one quarter of project costs. Indirect estimates suggest that corruption-related losses may amount to 30 percent of generated power in some countries.

Our existing evidence is fragmentary and open to wide margins of error, however. And, as the next section discusses, evidence to date suggests that perceptions measures in particular may not be able to provide any strong degree of accuracy regarding the extent and impact of corruption.

\section{Problems of Perception}

Perceptions measures designed to capture the extent of grand corruption appear reasonably stable over time, and they correlate with a number of objective indicators that we might expect them to correlate with (broad measures of development and factors such as the extent of regulation, for example). Perceptions of corruption in a given country are also broadly correlated across different surveys (even when these survey noticeably different groups). Nonetheless, there are reasons to believe that broad aggregate

\footnotetext{
${ }^{7} \mathrm{http}: / /$ www.worldbank.org/transport/roads/rd_tools/rocks_main.htm
} 
perceptions indices are inaccurate, particularly in their use as proxies for corruption in infrastructure.

It is important to emphasize that these indices measure perceptions of corruption, not corruption itself. Argentina's TI CPI rank dropped precipitously from 5.2 in 1995 to 2.8 in 2002 (Seligson, 2005). This may reflect declining governance, or perceptions may have been altered by the financial crisis, which began to unfold in 1999. In Peru, tapes of the head of the National Intelligence Service bribing legislators and others precipitated a significant drop in the country's Corruption Perceptions Index -it fell from 4.4 in 2000 to 3.5 in 2004. But it is worth noting that the collapse came after the tapes were released. There was no significant change in the index prior to the release of the tapes. The 1998 and 1999 rankings were 4.5, placing Peru ahead of the Czech Republic and the Republic of Korea, for example, even as over 1,600 Peruvians were receiving bribes from the intelligence service. Furthermore, the CPI continued dropping even as national polls suggested that the percentage of transactions which involved paying a bribe fell from 6.4 to 4.5 2002-2004 (Ausland and Tolmos, 2005). ${ }^{8}$ This evidence that the CPI acts as a 'lagging indicator' even during perhaps the largest corruption scandal in recent history is a concern, if the index is to be used to guide policy and investment decisions. ${ }^{9}$

As further illustration, Zimbabwe is a country that has seen a statistically significant increase in the perception of corruption over the period 1996-2004 according to the WBI control of corruption measure, for example (Kaufmann et. al., 2005). It has also entered a more widespread period of a crisis of governance. It is very plausible to imagine that this crisis of governance has increased levels of corruption, but it is also possible to imagine that a generally increased level of interest in the country and its broader problems has increased perceptions of corruption. For example, a Factiva search of major news sources worldwide found that there had been a doubling of news stories on Zimbabwe between the 1996-2000 period and the 2000-2004 period (Table 3). ${ }^{10}$ There had also been an increase in the percentage of stories which mentioned corruption-from 3.5 to 4.8 percent. This one third increase in the proportion of stories mentioning corruption is only about the same size as the increase in the percentage of stories mentioning Africa that also mentioned corruption, however. Compare this to the tripling of stories mentioning Zimbabwe which also use the word 'crisis,' far ahead of the statistics for Africa as a whole. Over 15 percent of stories mentioning Zimbabwe used the word 'crisis,' compared to less than 5 percent mentioning corruption. It is surely plausible to argue that

\footnotetext{
${ }^{8} \mathrm{We}$ will see that there is evidence that the CPI correlates more closely with petty than grand corruption (Knack, 2006), but the Peru case is one example of the CPI not even tracking survey data on petty corruption very well. More broadly, Svensson (2005) notes that cross-country survey evidence regarding incidence of bribes is not significantly correlated with expert perceptions once GDP per capita is taken into account. Again, a survey of experts predicted that 54 percent of African respondents would suggest that they had been victims of corruption in the past year, whilst a population survey of Africans themselves suggested that only 13 percent reported being victims of corruption in the past year (Arndt and Oman, 2006).

${ }^{9}$ Exacerbating this problem, and helping to explain the continuing decline in Peru's CPI rank as other indicators suggested the corruption situation was improving, is that the CPI often incorporates data that is two to three years old.

${ }^{10} \mathrm{http}: / / \mathrm{www}$. factiva.com/, search run 09/12/06.
} 
the image of increased corruption is based at least as much on this widespread reporting of a crisis as much as it is on a far smaller increase in the percentage of stories discussing corruption itself. Across countries, the fact that the WBI measure for control of corruption has a correlation coefficient of 0.95 with both WBI government effectiveness and rule of law measures suggests that it may be very difficult to tease out concerns regarding corruption with broader concerns regarding governance in general using perceptions indices (Thomas, 2006).

This is not to argue that when respondents are asked to think about corruption, they in fact only think about general levels of crisis or weak governance -there is good evidence that this is not the case (Kaufmann et. al., 2006). It is only to point out that general concerns abut a country are likely to play a significant role in responses to a question which is based on perceptions of an opaque, amorphous subject. Aggregating perceptions scores from different sources does not necessarily improve the problem. Variation in sources for country scores within a given year and across years and lack of independence between sources both reduce accuracy. This increases the magnitude of variation between scores required to declare a 'statistically significant' difference in perceived corruption -a variation which is already quite large. It also makes comparing scores for a country over time problematic (Knack, 2006, Arndt and Oman 2006).

Where we have estimates of the signal to noise ratio in corruption perceptions, the results are not reassuring. Olken (2006) finds that villager perceptions of corruption in village road projects are correlated with objective measures of corruption estimated from expenditure tracking and physical audits of the roads ('estimated corruption'), but the correlation accounts for little of the variation in perceptions. A 10 percent increase above the mean in the objective measure of corruption (reflecting an increase in missing expenditures equal to 2.4 percent of total expenditures) is associated with an increase in the probability that a respondent would perceive corruption of 0.3 percent (from a baseline of 36 percent). These are marginal effects, but if they held, this suggests that moving from no objective evidence of corruption in the project to the road not being built at all because 100 percent of expenditure went missing would increase the proportion of villagers who reported corruption by 12 percentage points.

Personal characteristics were significantly more correlated with corruption perceptions than were levels of estimated corruption. Beliefs about corruption in Indonesia were strongly correlated across different levels of government (those who believe the President was corrupt were far more likely to believe that the village head was corrupt). Bettereducated and male respondents were much more likely to report corruption, and the impact of education, for example, on likelihood of reporting corruption was far greater than the impact of increases in estimated corruption in the project itself.

Particularly significant as a determinant of perceived corruption at the project level was ethnic heterogeneity. Moving from a village that was ethnically homogeneous to the most ethnically diverse village in the sample increased the likelihood of a villager reporting corruption in the project by 50 percentage points. This bias is particularly important because estimated corruption was significantly negatively related to measures 
of heterogeneity. Moving from a village that was ethnically homogeneous to the most ethnically diverse village in the sample was associated with a decrease in the level of missing expenditures of 26 percentage points. At least in this case, ethnic heterogeneity led to lower trust, perhaps as a result increasing monitoring which in turn reduced estimated corruption even as perceived levels of corruption were higher.

Furthermore, the presence of public interventions designed to reduce corruption in the roads projects (inviting villagers to community meetings and providing anonymous comment forms) increased the perception of corruption in the project while doing comparatively little to reduce actual corruption. The private threat of audits made to the project director did little to reduce perceptions of corruption but significantly reduced estimated corruption levels.

In other words, even at the level of the village project, perceptions of grand corruption are a weak guide to actual levels of corruption and subject to systemic biases. This problem is surely considerably larger at the level of the country, where the social distance between the corrupt individual or activity and the survey respondent is likely to be far greater.

\section{Perceptions, Surveys and Outcomes}

This may be why evidence from survey instruments suggests that perceptions indices are poorly correlated with other measures of grand corruption. Regarding country averages for the question 'how often firms like yours need to make extra, unofficial payments to gain government contracts?' answers to this question are correlated only weakly with Transparency International rankings (Table 4). Looking at business environment datasets (Table 5), the results suggest that surveyed corruption in contracting is insignificantly related to TI CPI scores. Transparency International corruption perceptions rankings correlate far more strongly with petty corruption questions in the BEEPS data than with grand corruption (the TI measure correlates better with payments for utility connections and licenses than with payments for government contracts, for example). Knack (2006) demonstrates this result for the WBI corruption index as well as the TI measures. But Knack also notes that, as measured by frequency and scale of reported bribes, petty corruption appears to be only weakly correlated to levels of grand corruption.

We have seen that survey evidence suggests that corruption in construction and infrastructure is weakly correlated with general corruption levels. Given in addition the weak relationship between surveyed general corruption levels and perceptions of corruption, it is perhaps unsurprising that there appears to be no link between surveyed measures of infrastructure corruption and general perceptions measures. Table 4 suggests no link between construction firm BEEPS survey responses regarding corruption and the CPI. Looking at petty corruption in infrastructure and CPI measures, the (little) available data suggests no significant correlation between perceptions of corruption in getting an electricity connection and CPI scores (Table 6). 
Perhaps partially as a result, general perceptions measures are not robustly correlated with infrastructure outcomes. For example, Estache et. al. (2006) report that a general measure of perceived country-level corruption is associated with lower energy use. At the same time, they found telecoms access positively associated with perceived corruption while measures of access to water were not correlated either way with perceived corruption. $^{11}$

\section{Estimates of Petty Corruption in Surveys}

Surveys of service users appear to be a commonsense tool to estimate levels of petty corruption in infrastructure, given that the average respondent is likely to have personal experience of the transactions that can become corrupted. Nonetheless, it is worth noting that even here, survey answers can apparently involve some uncertainty. The Investment Climate Survey results suggest a very high correlation between cross-country estimates of corruption in getting connections to electricity, water and telephone services, despite considerably lower correlations with a number of other corruption variables (See Table 6 ). If the data reflects reality, it suggests that even despite the very different nature of the sectors (levels of competition, size of firms, involvement of the private sector and so on), corruption is determined almost solely by national-level factors that vary insignificantly between sectors. Perhaps more plausibly, and given that we believe that corruption does significantly vary by sector, the data may reflect a common perception driven by anchored estimates rather than very similar levels of petty corruption. ${ }^{12}$

Significant variation within countries in the reported level of petty infrastructure corruption is suggested by the 1999 BEEPS survey. The survey asks respondents how often firms like theirs have to bribe to get connected to public services such as telephone and electricity connections, with answers ranging between 'always' (given a value of one) and 'never' (given a value of six). Figure 1 displays the average and standard deviation of answers to this question across countries, compared to the average answer across all countries. As can be seen, only in the case of Estonia does the standard deviation not overlap with the cross-country average.

There are notable country differences (the percentage of firms answering 'never' varies between 31 percent in Ukraine and 92 percent in Estonia). Nonetheless, the variation in answers within countries is considerably larger than the variation across countries, to the extent that the great majority of average country responses are unlikely to be statistically

\footnotetext{
11 These results, positive and negative alike, are open to all of the usual concerns with econometric exercises regarding questions of causality and the stability of coefficients in the presence of multicolinearity and omitted variables. Given that corruption is likely to be centered around urban water supply systems, it might be that better results would be uncovered using access to a private water connection in urban areas, but this data is available for fewer countries.

${ }^{12}$ Anchoring is a problem common to survey work, and has a particular impact where questions are vague and respondents are unsure of the answer. Anchoring involves answers to subsequent questions being considerably affected by an initial question or piece of information, even if it is completely irrelevant (Tversky and Khaneman, 1974).
} 
significantly different from each other. ${ }^{13}$ This may well reflect different interpretation of the intermediate categories (mostly, frequently, sometimes, seldom), but it is also likely to reflect the fact that different types of firm in different parts of the country face different risk of infrastructure corruption victimization. As a result, while there is undoubtedly useful information in these survey responses regarding petty corruption in infrastructure that can be used for econometric analysis, this set of answers would not be suitable to determine differing policy positions or prescriptions at the sector level between countries.

Uncertainty or within-country variation in response as well as, perhaps, the limited development impact of petty corruption in infrastructure, may account for the apparently weak relationship between surveyed petty corruption levels and infrastructure outcomes. Table 7 reports on correlations between answers to Business Environment Survey questions (the percentage of firms who say gifts are required for connections to infrastructure) and sectoral outcome indicators controlling for GDP per capita. There is a positive and significant link between the reported extent of petty corruption in telecommunications and the waiting list for a telephone mainline. Otherwise, the relationship between our indicators of infrastructure outcomes and measures of petty corruption are insignificant. ${ }^{14}$ It should be emphasized that all of these results cover a very small number of observations (11-23 countries). Nonetheless, based on the data we have and as with earlier studies linking general corruption perceptions measures to infrastructure outcomes, infrastructure-specific survey measures of petty corruption also appear to be weakly related to outcomes. We will see that this may be in part because the form of petty corruption caught by such surveys may be some of the least damaging in terms of outcomes.

\section{How Much Can Surveys Tell Us about Grand Corruption?}

The approach of surveying firms which are likely to be directly involved in grand corruption again appears likely to produce more accurate measures than perceptions indices.

Once more, there remain difficulties with these surveys too, however. Not least is the issue of honest and accurate reporting. Direct questions asking business owners to estimate the percent of their own costs that are accounted for by bribe payments can illicit considerably different responses as a result of these problems. Henderson and Kuncoro

\footnotetext{
${ }^{13}$ The average of within-country standard deviations is 1.2 compared to the standard deviation of country averages which is 0.4 .

${ }^{14}$ Although there are better dependent variables for water, and non-technical losses would be a better dependent variable for electricity (again, this is not available for as many countries). We also have some (very) preliminary evidence of a link between estimates of corruption in construction and infrastructure outcomes for roads from Investment Climate Survey data. Table 2 reports that average percentages reported for the value of a gift required to secure a government contract reported by investment climate surveys is negatively and significantly correlated with the percentage of a country's roads which are paved after controlling for GDP per capita. Once more, this is a weak proxy for quality, but available for more countries than better measures. Source: http://iresearch.worldbank.org/ics/jsp/index.jsp.
} 
(2006) suggest that differences in survey design and technique account for the difference in estimates of corrupt payments between 10.5 percent of costs found in their survey of Indonesian firms and 3 percent of profits found by the Indonesian Annual Survey of Medium and Large Enterprises. The problem of accuracy may be magnified when questions are less specific, or asked about 'firms like yours,' or levels of corruption in general.

The BEEPS survey data allows us to see how significant such issues of interpretation, specificity and insufficient knowledge might be, even in perhaps the strongest survey that covers corruption issues. The survey asks for the percentage of firm sales to the state sector and the unofficial payments made by firms in that industry to secure government contracts as a percentage of government contract values. The product of these two responses should be a reasonable indicator of respondent estimates of the percentage of total revenues paid in unofficial payments to secure government contracts for firms like theirs. The survey also asks for the percentage of total revenues accounted for by all unofficial payments and the percentage of those unofficial payments which are used to secure government contracts. The product of these two responses should also be a reasonable indicator of respondent estimates of the percentage of total revenues paid in unofficial payments to secure government contracts for firms like theirs. One would hope that these two different measures would be approximately equal:

\footnotetext{
(bribes for government contracts as a percentage of revenues)

$\approx$

(percentage of firm sales to state) * (percentage of government contract values paid in bribes) $\approx$

(percentage of revenues paid in bribes) * (percentage of bribes paid to secure government contracts)
}

Answers to the questions regarding total revenues accounted for by all unofficial payments and unofficial payments on government contracts as a percentage contracts were both measured in bands in the 1999 survey $\left(0 \%, 0 \% \diamond 1 \%\right.$ and so on).$^{15}$ In order to perform analysis we take the response as equal to the midpoint of the band. In the case of the last indicator in both cases $(>25 \%)$ the answer is assumed to be $35 \%$. This will create noise in the estimates, a subject returned to below. There are 297 firms from the BEEPS database with the requisite data and more than 25 percent of sales to government (such firms should be better informed about the size and extent of bribery for contracting with government). This provides us with two estimates from the same firm of total payments to secure government contracts as a percentage of revenue.

A simple regression takes the product of percentage of total revenues in unofficial payments multiplied by percentage of unofficial payments to secure government contracts as the dependent variable and the product of percentage of contracts in bribes multiplied by percentage of sales to government as the independent variable. If respondents were answering consistently based on accurate knowledge of firm revenues and levels of corruption, we would expect a coefficient of one, an R-squared close to one and an intercept near zero. In fact, the independent variable enters highly significantly,

${ }^{15}$ This has changed in subsequent versions of BEEPS. 
but with a coefficient of 0.23 , while the intercept, at 0.65 , is significantly different from zero and the R-squared is 0.14 (see Figure 2). ${ }^{16}$ Reversing the approach, with percentage of government contracts paid in bribes multiplied by percentage of sales to the state as the dependent variable, the coefficient rises to 0.6 , however the intercept also rises, to 2.1 (with a 95 percent confidence interval of 1.6 to 2.6). This is worth comparing to the average value for the dependent variable of 2.9.

Given the issue of measurement in bands, it might be better to calculate the lowest and highest potential percentage of revenues going to bribes for government contracts by each method and calculate in what percentage of cases the two bands overlap (see Figure 3 for an illustration). Using this method, 54 percent of estimates overlap. This number drops to 46 percent of estimates amongst firms which report some level of bribe payments as a percentage of government contract values. ${ }^{17}$ The results in part reflect different average estimates produced by the two calculations of bribes for contracts as a percentage of revenues. The product of percentage of total revenues in unofficial payments multiplied by percentage of unofficial payments to secure government contracts averages 1.3 percent. The product of percentage of contracts in bribes multiplied by percentage of sales to government averages 2.9 percent. $^{18}$

There is some considerable level of information in the survey results regarding the extent of corruption in government contracting, then. Nonetheless, there is also considerable noise and/or bias (as is usual in surveys), suggesting the need for caution in use of the results. Beyond banding, further noise is added by the fact that respondents are sometimes asked to consider their company and sometimes firms 'like theirs'. Some questions refer to sales, some to contracts and some to revenues. Nonetheless, the results surely also suggest some uncertainty about the usual size of bribe payments to secure government contracts on the part of respondents.

Again, amongst the firms surveyed by BEEPS were 376 construction companies. We can use the data to examine the differences between construction firms and others when it comes to corruption in Eastern Europe and Central Asia (Table 8). It appears that construction firms in the sample think it is more common to pay bribes in their industry than do firms in other industries, that firms like theirs spend a larger percentage of revenues on bribes, and they bribe more frequently to get licenses, deal with taxes and get contracts. Adding a number of controls, it appears (unsurprisingly) that private construction firms where the state is the largest customer are likely to report particularly

\footnotetext{
${ }^{16}$ It is worth noting that this is not a test of a model, but what should hopefully be an identity relationship. Not all sales to government involve a formal contract, this may account for some of the variation between the two estimates.

${ }^{17}$ i.e. assuming that the answer to question 30 is not 1.

${ }^{18}$ The ranges based on the minimum and maximum answers from banded responses are 0.8 to 2.0 for the first estimate and 1.8 to 4.7 for the second estimate. It is worth emphasizing this overlap (the standard deviations of the averages also overlap). This may suggest that the most plausible range for the percentage of revenues going to bribes for this group of firms is 1.8-2.0.
} 
high corruption in their industry (Table 9). ${ }^{19}$ These results are highly statistically significant, again suggesting the utility of the survey approach.

At the same time, the BEEPS survey was not designed to provide a large dataset for exploring construction alone, and it is perhaps unsurprising that, partially as a result, evidence regarding the variation in corruption across countries in the sector is not strong. As we have seen, one of the BEEPS questions is "when firms in your industry do business with the government, how much of the contract value would they typically offer in additional or unofficial payments to secure the contract?" Answers, expressed as a range of percentages of the contract value, are on a six point scale from zero to above twenty percent. Taking construction firms in the 1999-2000 BEEPS dataset which answered this question, we can see how much the answers tell us about sector-level corruption using country dummies. All but nine firms out of 143 report some level of bribery. How much of the variation in estimates of industry corruption by firms in this industry across countries is explained by which country the respondent is in? If construction firms were perfectly informed about the typical level of corrupt payments to government in their industry in their country and they understood and answered the question in the same way, we would expect 100 percent of the variation in answers to be explained by the country of residence of the respondent. In fact, around 14 percent of the variation can be explained, and none of the country dummies is statistically significant (Table 10, see Figure Four for Cross-Country variation compared to standard deviations). ${ }^{20}$ This performance is similar if we limit the analysis to private firms or to private firms which deal with the government.

A similar finding applies to the answer to the question "how often do firms like yours nowadays need to make extra, unofficial payments to government officials to gain government contracts?' -which is available for a considerably larger number of firms (Table 11). The variation explained by country dummies, which one would hope to be very high, is in fact very low (with an R-squared of 0.1 ). The results apply even if we remove those firms that say companies never pay such bribes, suggesting that reticence about reporting such behavior does not lie behind the result. Overall, this suggests that we can say little with statistical confidence about which countries in the 1999 BEEPS dataset have more corrupt construction industries than average based on questions asking construction firms themselves how corrupt their industry is.

It should be noted that the variation will be large enough to show that construction in Azerbaijan (the worst performer) is significantly more corrupt than the best countries (Uzbekistan, Poland and Estonia). ${ }^{21}$ And the survey results are useful for further econometric analysis of the causes and consequences of corruption. However, the survey

\footnotetext{
${ }^{19}$ Although within a subsample of construction industry firms, it appears that firms that do not deal with the government estimate the size of bribes paid on government contracts as being significantly smaller than do firms who deal with the government.

${ }^{20}$ The F-stat. is 1.43

${ }^{21}$ It is also worth noting that this situation may be considerably better with the larger samples of the 2005 dataset.
} 
was not designed for, and would not be suitable for, strongly differentiating levels of corruption within sectors across countries.

Questions are not exact, and open to subjective interpretation. One cannot expect one person in a company to have perfect knowledge of company revenues, contract sizes and, in particular, the size of bribes paid. Furthermore, there are many different types of construction firm, and they will frequently be working with different levels of government or different departments within those levels. But if these factors are what accounts for the variability of responses, it suggests the danger of assuming one indicator can accurately gauge levels of corruption even regarding one distinct activity at the level of the sector (let alone all activities at the level of the country). This suggests the danger of using even survey evidence as an 'actionable indicator' of levels of corruption.

Survey responses are likely to be the most plausible method to determine the extent and level of payments linked to petty corruption in infrastructure and grand corruption in construction. At the same time, even answers regarding petty corruption have to be treated with some care. Furthermore, there is significant evidence that corruption payments vary considerably across and within sectors within the same country, suggesting the need for surveys with large enough samples of construction industries and specific enough questions to allow for inter-sectoral analysis. Finally, the firm survey is likely to be an inappropriate instrument to illuminate grand corruption within utility firms, because infrastructure provision tends to be so concentrated.

\section{Its Not How Much You Divert, But How You Divert It That Matters}

Even were data on the size and frequency of payments significantly improved, a focus on such payments may underestimate and misplace the economic damage done by corruption in infrastructure projects. One source of mis-estimation is to confuse the financial and economic costs of bribe payments themselves. Payments are not a 'deadweight loss,' in that bribe recipients can and do spend the money (this is sometimes how they are caught). More importantly, the major damage done by corruption is probably not the narrow financial loss of bribe payments but the economic cost in terms of skewed spending priorities, along with substandard construction and operation.

Imagine a road project that costs $\$ 1$ million to build but generates $\$ 320,000$ in economic returns each year after construction for 10 years. The project's overall economic rate of return is about 30 percent (the average ERR for World Bank transport projects exiting FY97-02). If the project had suffered from collusive bidding, and this had raised the price of construction by 20 percent, to $\$ 1.2$ million, the project's ERR would drop to 26 percent. $^{22}$ This is a significant decline, but it still leaves the project at more than double the 'hurdle rate' of a 10 percent ERR. ${ }^{23}$

\footnotetext{
${ }^{22}$ This (and subsequent calculations) view the corrupt payment as a transfer but accounts for a (high) marginal cost of government funds lost to corruption of 1.50 (a fifty percent deadweight loss).

${ }^{23}$ This is approximately the economic impact of poor road construction suggested by Olken (2004).
} 
Imagine instead that the bidder agreed a contract price of $\$ 1$ million, but used insufficient and substandard materials to build the road, spending only $\$ 800,000$ on construction and pocketing the remaining $\$ 200,000$. This reduces the road's traffic capacity so that yearly economic returns fall by a quarter. It also shortens the useful life of the road to five years. This would reduce the overall ERR to 15 percent. The same financial level of corruption has a considerably larger economic impact in this case, reducing the ERR by 15 percent rather than 4 percent.

What if construction firms had used $\$ 200,000$ to pay off legislators to divert money from operations and maintenance funds for the construction of this road, and recouped their expenditure through overbidding or poor construction? At this point, with the new road project sucking up resources from maintenance of existing roads, reducing traffic capacities and road life across the network, economic rates of return might turn negative.

In short, the nature of corruption can have a significant impact on the economic damage caused by that corruption, even if the financial losses are the same size. Bribery payments which are made to deliver quality projects and services at inflated prices may be far less damaging than corrupt activities which impact the quality of delivery or the type of projects undertaken.

Benjamin Olken's (2004) experiment in Indonesia, monitoring corruption in road construction, provides a real-world example. In the case study by Olken, nearly all of the corruption took the form of missing quantities, not price mark-ups. The prices that project managers reported paying for goods were the prices actually paid. Project managers made corrupt incomes by purchasing lower quantities or stealing construction materials. Olken trials two approaches to the reduction of corruption in road-building -extending project audits and encouraging greater community participation. In both cases, the cost in terms of money and time of the anti-corruption interventions is larger than the financial cost saving from reduced theft of materials and wages by corrupt officials. In other words, using a purely financial metric of the benefits of anti-corruption activities based on the cost of the activity and the size of the theft suggests that the best approach is no approach -it isn't worth the cost of trying to reduce corruption.

Taking a broader view of the impact of corruption suggests a markedly different conclusion, however. Olken estimates that a marginal dollar of materials stolen from a road project reduces the discounted benefits from the project by $\$ 3.41$ because of the shorter life of the road when built with insufficient material. When accounting for the reduced value of the road due to corruption, the net benefit of both anti-corruption interventions becomes positive. The fully-costed $\$ 500$ expenditure on an audit produces gross economic benefits of $\$ 1,155$, for a net benefit of $\$ 655$, for example.

At the national level, the recent rural investment climate survey in Indonesia reported that a growing percentage of the country's road network is falling into disrepair. This is in part because of a considerable and growing misallocation of financing from maintenance to construction. At the start of the 1990s, road maintenance accounted for about 47 percent of the central government grants to districts for roads. By the end of the decade 
this had dropped to 15 percent. Expenditures should be more than seventeen times their current level to maintain the existing road stock in good condition. It is plausible to imagine this misallocation is connected in some part to the incentives created by corruption, although of course it also has a number of other institutional and political causes. $^{24}$

Looking at petty corruption in the water sector, those unconnected to the water grid frequently pay ten or more times the amount per liter for water than do connected consumers. Willingness to pay valuations in India suggest that even very poor people would pay more to keep water services and considerable amounts (as much as twice current average water bills) to see improved service quality (Dutta, 2005). ${ }^{25}$ The consumer surplus to a (quality) connection is large. This is, of course, why people are willing to bribe for a legal or illegal connection to the supply -- $\$ 2.64$ per connection in India, for example.

These figures are significant, but in some part they involve payments for services that undercompensated water staff should be providing anyway -they are a transfer to get the job done, perhaps one of the least harmful forms of corruption. Compared to payments that encourage illegal activities, or payments to avoid law enforcement, payments to encourage legal activities have less impact on economic outcomes (see Figure 5). Furthermore, compared to official connection charges of around \$140 (Franceys, 2005) or a monthly water bill in Delhi averaging about $\$ 1.29$, willingness to pay figures considerably larger and a tenfold price difference between connected and unconnected consumers, illegal connection payments are not so significant in and of themselves. It is clear that even after speed payments, there is a considerable consumer surplus to a water connection. That corruption reduces the quality of water services and diverts connections is likely to be a far larger source of economic harm than the scale of petty bribes for connections. This may help to account for the apparently weak connection between petty bribes and sector outcomes that we observed earlier.

Again, a macroeconomic perspective suggests that the major impact of corruption in infrastructure is usually going to be on what is built where, not how much is paid to build or connect it. The incentives to spend money on building infrastructure rather than operations and maintenance, the incentive to build poor quality infrastructure in the wrong place and the incentives to poorly operate it probably account for the bulk of the negative development impact of corruption. ${ }^{26}$ Such incentives may help to explain crosscountry evidence suggesting an impact of weak institutions and high corruption out of all proportion to a ten or twenty percent mark-up in the costs of investments. Indeed, the cross-country evidence suggests a real return to public investment in Africa that is insignificantly different from zero (Devarajan et. al. 2002). Of course, this is due to a

\footnotetext{
${ }^{24}$ It is worth noting that where there is a risk of catastrophic failure absent O\&M, not only is maintenance carried out more regularly but also cost recovery is more prevalent-compare road transport with air transport or energy.

${ }^{25}$ See also Komives et. al. 2005

${ }^{26}$ An important case of corruption creating incentives to poorly operate infrastructure will be in the case of payments to avoid environmental regulation, which is likely to have a significantly larger economic impact than the deadweight loss of corruption payments.
} 
number of factors beyond corruption, but it is likely that the skewed incentive structure in which corruption plays a role (and is a symptom) is a significant part of this low return. ${ }^{27}$ Differences across countries in the types of corruption (damaging or less so) that are prevalent may also account for what appears to be a complex and context-specific relationship between general measures of corruption and growth outcomes across countries (Rock and Bonnett, 2004).

Nonetheless, our knowledge about levels of particularly harmful corruption in infrastructure (that which involves diversion and substandard construction) is minimal. As we have seen, existing measures of corruption available across countries and regions tend to be based on perceptions, which tend (if anything) to measure the extent of the petty corruption that interviewees experience directly. Again, we have seen that most individuals and even firms appear only partially informed as to the extent of 'grand' corruption involving officials and contractors. Construction and infrastructure corruption varies considerably across countries with similar scores on overall country-level measures of corruption. And finally, all of the usual measures of corruption relate to the extent and scale of bribe payments. They do not provide information on the type of bribe payment, the level of theft of materials, the construction codes being ignored and so on. Without such measures we can say little about the extent of the most damaging forms of corruption in infrastructure across different countries. ${ }^{28}$

\section{What Does This Mean for Measurement of Corruption in Infrastructure?}

Of course, such measures will be some of the hardest to uncover. They are not part of everyday experience, so they are difficult to pick up in general surveys. Even large-scale company surveys such as BEEPS do not yet tackle the non-financial elements of corruption. The response should not be to 'live with the measures we have,' however, as these are likely to be poorly designed to determine the extent of the problem and the success of remedial actions in infrastructure. One approach would be to look at the most damaging consequences of corruption, which are more easily measurable.

Minimizing the damage done by corruption involves countering the incentives to build the wrong thing and to build and then operate it badly. If this is our concern, we should focus attention on macro-sectoral issues such as overall budgeting and project selection and on physical auditing of the status of physical capital. We should see if budgets are adequate (and paid) for operations and maintenance, if O\&M is actually carried out in a way that maintains infrastructure quality, if the process for selecting projects picks those with high economic return and if the new infrastructure is well constructed. If all of these conditions are met, we will know that the impact of corruption in infrastructure on overall

\footnotetext{
${ }^{27}$ In Bank projects, a one standard-deviation increase in the Kaufman-Kraay rule of law measure increases the chance of a successful project by sixteen percentage points (Dollar and Levin, 2005)

${ }^{28}$ Grand corruption, at least, may be a comparatively ineffective substitute for lobbying. Campos and Giovanni (2006) use the BEEPS data to suggest that firms which lobby more bribe less and report far higher levels of influence over government decisionmaking. It may be, then, that governance reforms which increase the potential for lobbying will have a negative development impact even if they simultaneously reduce levels of corruption.
} 
development will be comparatively small. This suggests a focus on medium-term expenditure frameworks, public expenditure tracking surveys and physical audits as key corruption measurement tools in infrastructure.

An advantage of such an approach is that it may be easier to find good metrics than in the case of sector- and type-specific direct corruption indicators. Rather than relying on perceptions or expert intuition, an approach that relies on inputs and outputs can use objective indicators. We have good benchmarks for the cost of maintaining different classes of road, for example. Is the national budget putting aside adequate resources to fully maintain the country's road network based on those benchmarks? We have many years of experience in project evaluation which should allow us to determine if project selection in a given sector appears to be following rational procedures or is driven by other concerns. It is a comparatively simple engineering task to determine if a road or pipeline has been constructed and maintained adequately or poorly through a physical audit. ${ }^{29}$ Further work is needed (and is underway) in the area of sectoral approaches to corruption that could flesh out such ideas (see Table 12), but the model provided by REDIs (Recent Economic Developments in Infrastructure) already incorporates much of the required analysis for such an approach. ${ }^{30}$

Such a measurement approach would involve errors of commission and omission. The 'wrong' project can be selected on the grounds of political interest absent private gain. Poor construction and maintenance can be the result of incompetence and inefficiency as well as corruption. But the project still remains the 'wrong' project, for whatever reason it was selected. Poor construction and maintenance remains a significant drag on development performance whatever its cause. And as suggested by the very high correlations between the perception-driven measures of corruption and governance that we have, disentangling different types of governance failure will be a very difficult, and quite possibly mistaken, exercise regardless. As a result, the errors of commission are comparatively minor in terms of the indicators' abilities to measure overall development impact.

Regarding errors of omission, it may be that well-built projects involve corruption which raises the price of construction or that consumers accessing well-maintained networks still have to make speed payments or are illegally connected. This is, of course, a legitimate issue of concern. Measuring contract prices against benchmarks and business and customer surveys can play an important role in uncovering and measuring such corruption. But it is worth repeating that his type of corruption is likely to be less damaging in terms of development impact. ${ }^{31}$

\footnotetext{
${ }^{29}$ For example, in the Philippines, physical audits combined with a GIS system are being used to determine if roads and bridges actually exist and what state they are in as part of a drive towards improved transport governance. Furthermore, especially at the level of project selection and measurement of infrastructure quality, there is no need to survey 100 percent of proposed projects or infrastructure stocks -a random representative sample would suffice to suggest if the sector is performing well.

${ }^{30}$ REDIs or equivalents have been completed in a number of countries including Colombia and Morocco.

${ }^{31}$ Of course, this will depend on the level of such payments -if they start doubling contract prices, for example, they will become a serious issue, but luckily also much easier to spot.
} 
At the same time, we should extend and expand survey work, increasing the focus on petty corruption in infrastructure and grand corruption in construction. Accuracy will be improved if surveys are either limited to or large enough to be representative for a particular subsector, clients of a particular firm or suppliers to a particular ministry or department (indeed BEEPS have doubled in size since the 1999 survey used in this paper). ${ }^{32}$ With petty corruption, the role for increased use of consumer scorecards and other consumer survey methods is considerable. There may also be a role for survey/interview instruments aimed at international infrastructure providers that might allow for anonymous data collection regarding grand corruption in infrastructure provision itself.

Even with more survey work, however, it is likely that if want measures for 'progress' in sector level anti-corruption efforts aimed at grand corruption in infrastructure in particular we should also use more easily measured output indicators which have been related to corruption variables rather than the variables themselves (measures such as percentage of roads in good condition, transmission and distribution losses). Output measures may better indicate reduction in development impact of corruption in infrastructure and greater ease of measurement for such indicators will allow for more accurate determination of change over time.

\section{What Does This Mean for Anti-Corruption Policy?}

Robust general findings from surveys which apply to the infrastructure sector are useful for general policy advice. For example, firm survey data tend to suggest that companies that face more red tape and/or spend more time dealing with government pay more in bribes (Gaviria, 2002, Henderson and Kuncoro, 2006, Renikka and Svensson, 2006). Again, BEEPS data suggests that bribery was more common to get connected to electricity and telecommunications for firms in less democratic slow-growing countries with less-developed infrastructure, public ownership of utilities and limited competition (Clarke and $\mathrm{Xu}, 2002$ ). These results match broader findings regarding where corruption is likely to be more common, and might suggest broad reform approaches to reduce the extent and impact of corruption -transparency, participation, competition, reduced discretionary powers, removal of unnecessary regulation, improved financial management and extended auditing (Cavill and Sohail, 2007, Seldadyo and de Haan, 2005, Lederman et. al., 2005). ${ }^{33}$

\footnotetext{
${ }^{32}$ In order to gauge and improve accuracy approaches might include: surveys should ask directly comparable questions (not switching between 'firms like yours' and 'your industry,' for example); they should ensure specificity if necessary through careful definition as part of the question; question order should vary between firms; there should be multiple approaches to asking the same question in different ways (including 'anchored' and 'unanchored' responses); and interviewers should re-survey some respondent after the passage of time and ask multiple respondents from the same firm (again, done with subsequent BEEPS). One might want to vary questions between banded and exact response rates, although exact response questions are likely to illicit lower levels of response (Lynn et. al., 2005).

${ }^{33}$ Estache et. al. (2006) suggest the conditional impact of reform (privatization and independent regulation) is to reduce the impact of perceived corruption on energy access (although it has no effect on water).
} 
At the same time, we need to be aware of the limits of our empirical knowledge about corruption in infrastructure, and so the limits to our policy responses. On the one hand, there appears to be very strong anecdotal evidence that bribery for government contracts is the norm in many countries. On the other hand, firm surveys suggest that the frequency or scale of bribes differ dramatically within the same industry in a country. This is a sign of the fragility of our knowledge regarding corruption even in an area where it is widely agreed to be a major development problem. It is possibly a sign that corruption is 'ad hoc' and opportunistic suggesting that anticorruption approaches may need to vary considerably within sectors and between countries. As a result, we need to be cautious in drawing cross-country sector policy conclusions from analysis based on corruption perceptions alone or even limited survey evidence.

It may be particularly unwise to use cross-country or cross-time analysis of the extent of corruption based on perceptions as a tool for aid targeting or differential project design requirements especially at the sectoral level. The existing sectoral data is inadequate for such a task and this is unlikely to change in the near term. Again, if corruption indicators are required for targeting or policy requirements, it is likely that objective indirect measures that reflect broader weaknesses of governance will be a better instrument at least until repeated large-scale infrastructure-specific surveys are carried out. Objective input measures might also have a role to play -perhaps including some Doing Business indicators on business regulation, or Global Integrity measures regarding the institutions of good governance. ${ }^{34}$ It should be noted, however, that these are not infrastructurespecific, and their relationship to governance outcomes is not firmly established.

Tools for a broad approach to improved governance in infrastructure would focus on improving budget, maintenance and project selection and implementation processes with a primary focus on quality. This will encompass state-owned enterprise reform, improved regulation (including transparency, participation and low-discretion rules) and increased competition (for and in the market as well as yardstick competition). It would highlight improved and more transparent processes for budgeting, project selection and oversight, including community-driven approaches. At both the sectoral and project level, one important element is likely to be a focus on paying for outputs based on independently verified physical audit.

A lens that focuses on the development impact of corruption suggests that a single project-focused and in particular a procurement-focused approach may be inappropriate. O\&M budgets in many developing countries are too low to sustain existing stocks of infrastructure -as reflected in poor indicators of quality. At the same time, donor projects are 'cherry picked' -the most attractive investment projects from the point of view of economic returns. These two facts help to reconcile high ERRs estimated for donor projects in Africa with very low overall returns to public investment and limited macroeconomic returns to aid. Low O\&M budgets and many poor project choices are both likely to be in some part connected to incentives created by poor governance and corruption. Taking a project approach to corruption would miss both of these impacts, which are frequently at the core of corruption's overall development impact.

${ }^{34}$ http://www.doingbusiness.org/, http://www.globalintegrity.org/ 
Furthermore, a procurement-centered approach is likely to miss a good deal of the corruption directly related to a project, including some of the most harmful forms. Theft of materials and bribes to cover up construction code violations both occur after the procurement process is complete, for example. The project may also generate downstream corruption in the form of petty bribes for connections, or tax and customs avoidance. As we have seen, these forms of corruption can make up the bulk of bribe payments and may also account for a considerable proportion of the economic harm caused. $^{35}$

Any comprehensive anti-corruption strategy in infrastructure should start at the level of the sector rather than the project or the procurement, then. The usual focus on the scale of improper payments and theft centers attention on particular anti-corruption strategies in projects --methods to benchmark construction prices to detect overbidding, for example. We should additionally focus on tools to reduce the most damaging consequences of corruption, because if these consequences are avoided, we will know that the impact of corruption in infrastructure on overall development will be comparatively small.

The issues of collusion or bid-rigging that raises contract prices and the issue of speed payments or bribes for illegal service remain significant development problems themselves, not least through their impact on trust in governance and reduced appetite of quality contractors to bid. Procurement procedures, price benchmarking, transparency, civic engagement, investigation --the full panoply of prevention and detection methods should be used to reduce corruption in construction that raises prices and encourages petty corruption. But if the right projects are selected and the resulting infrastructure is well built and maintained, the potential development impact of corruption is considerably reduced. Perhaps this broader concern with sector governance should be the main focus of the Bank's anticorruption agenda in infrastructure.

\footnotetext{
${ }^{35}$ Having said that, good contract design, especially if it involves output-based payments, can significantly reduce the potential development impact of corruption.
} 


\section{Bibliography}

Arndt, C. and C. Oman (2006) Uses and Abuses of Governance Indicators, OECD Development Centre Studies Series, Paris: OECD.

Ausland, A. and A. Tolmos (2005) Focus on Corruption: How to Secure the Aims of Decentralization in Peru by Improving Good Governance at the Regional Level, mimeo, Kennedy School, Harvard University

Campos, N. and F. Giovannoni (2006) Lobbying, Corruption and Political Influence, IZA Discussion Paper 2313.

Canning, D. and M. Fay (1996) Infrastructure and Growth, mimeo, World Bank.

Cavill, S. and M. Sohail (2007) Accountability Arrangements to Combat Corruption: Literature Review mimeo, Loughborough University.

Clarke, G. and L. Xu (2002) Ownership, Competition and Corruption: Bribe Takers Versus Bribe Payers World Bank Policy Research Working Paper 2783.

Davis, J. (2004) Corruption in Public Service Delivery: Experience from South Asia's Water and Sanitation Sector World Development 32, 1.

Devarajan, S., W. Easterly and H. Pack (2002) Low Investment is Not the Constraint on African Development Center for Global Development Working Paper 13.

Dollar, D. and V. Levin (2005) Sowing and Reaping: Institutional Quality and Project Outcomes in Developing Countries World Bank Policy Research Working Paper 3524.

Dutta, V. (2005) Public Support for Water Supply Reforms in Unplanned Sector: Empirical Evidence from an Urban Water Utility, mimeo, Center for Regulatory and Policy Research India Habitat Center, New Delhi.

Estache, A., A. Goicoechea and L. Trujillo (2006) Utilities Reform and Corruption in Developing Countries, mimeo, World Bank.

Franceys, R. (2005) Charging to Enter the Water Shop? The Costs of Urban Water Connections for the Poor Water Science and Technology: Water Supply 5, 6, 209-216.

Gaviria, A. (2002) Assessing the Effects of Corruption and Crime on Firm Performance: Evidence from Latin America, Fundación Pondo Investigación Económica en Colombia Working Paper 001482.

Gulati, M. and M. Rao (2006) Checking Corruption in the Electricity Sector, mimie, World Bank.

Henderson, J. and A. Kuncoro (2006) Corruption in Indonesia, NBER Working Paper 10674.

Hobbs, N. (2005) Corruption in World Bank Projects: Why Bribery is a Tolerated Anathema LSE DESTIN Working Paper 05-65.

Kaufmann, D., A. Kraay and M. Mastruzzi (2006) Measuring Governance Using CrossCountry Perceptions Data in S. Rose-Ackerman International Handbook on the Economics Corruption. Edward Elgar. 
Knack, S. (2006) Measuring Corruption in Eastern Europe and Central Asia: A Critique of the Cross-Country Indicators, World Bank Policy Research Working Paper 3968.

Komives, K., V. Foster and J. Halpern (2005) Water, Electricity and the Poor: Who Benefits from Utility Subsidies? Washington DC: World Bank.

Lederman, D., N. Loayza and R. Soares (2005) Accountability and Corruption: Political Institutions Matter Economics and Politics 17, 1.

Lynn, P., N. Buck, J. Burton, A. Jackle and H. Laurie (2005) A Review of

Methodological Research Pertinent to Longitudinal Survey Design and Data Collection ISER University of Essex Working Paper 2005-29.

Olken, B. (2004) Monitoring Corruption: Evidence from a Field Experiment in Indonesia, NBER Working Paper 11753.

Olken, B. (2006) Corruption Perceptions vs. Corruption Reality NBER Working Paper 12428.

Reinikka, R. and J. Svensson (2006) Using Micro-Surveys to Measure and Explain Corruption, World Development, 34, 2.

Rock, M. and H. Bonnett (2004) The comparative Politics of Corruption: Accounting for the East Asian Paradox in Empirical Studies of Corruption, Growth and Investment World Development 32, 6.

Seldadyo, H. and J. de Haan (2005) The Determinants of Corruption: A Reinvestigation mimeo, University of Groningen.

Seligson, M. (2005) The Measurement and Impact of Corruption Victimization: Survey Evidence from Latin America World Development 34, 2.

Soreide (2004) Corruption in international business transactions: The perspective of Norwegian firms, CMI Report R 2004:10, available on www.cmi.no, Chr. Michelsen Institute

Svensson, J. (2005) Eight Questions About Corruption Journal of Economic Perspectives 19,3 .

Thomas, M. (2006) What do the Worldwide Governance Indicators Measure? Mimeo, Johns Hopkins SAIS.

Tanzi, V. and H. Davoodi (1998) Roads to Nowhere: How Corruption in Public Investment Hurts Growth, IMF Economic Issues No. 12.

Tversky, A., \& Kahneman, D. (1974). Judgement Under Uncertainty: Heuristics and Biases. Science, 185, 1124-1130. 
Table 1: BEEPS: When firms in your industry do business with the government, how much of the contract value would they typically offer in additional or unofficial payments to secure the contract? Sample of construction firms

\begin{tabular}{|lr|}
\hline Bribe Size & \% Responses \\
$0 \%$ & 9 \\
Up to $5 \%$ & 37 \\
$6-10 \%$ & 39 \\
$11-15 \%$ & 9 \\
$16-20 \%$ & 3 \\
$>20 \%$ & 3 \\
\hline
\end{tabular}


Table 2: BEEPS: Correlation between average country answer across industries and average country answer for construction for three corruption variables

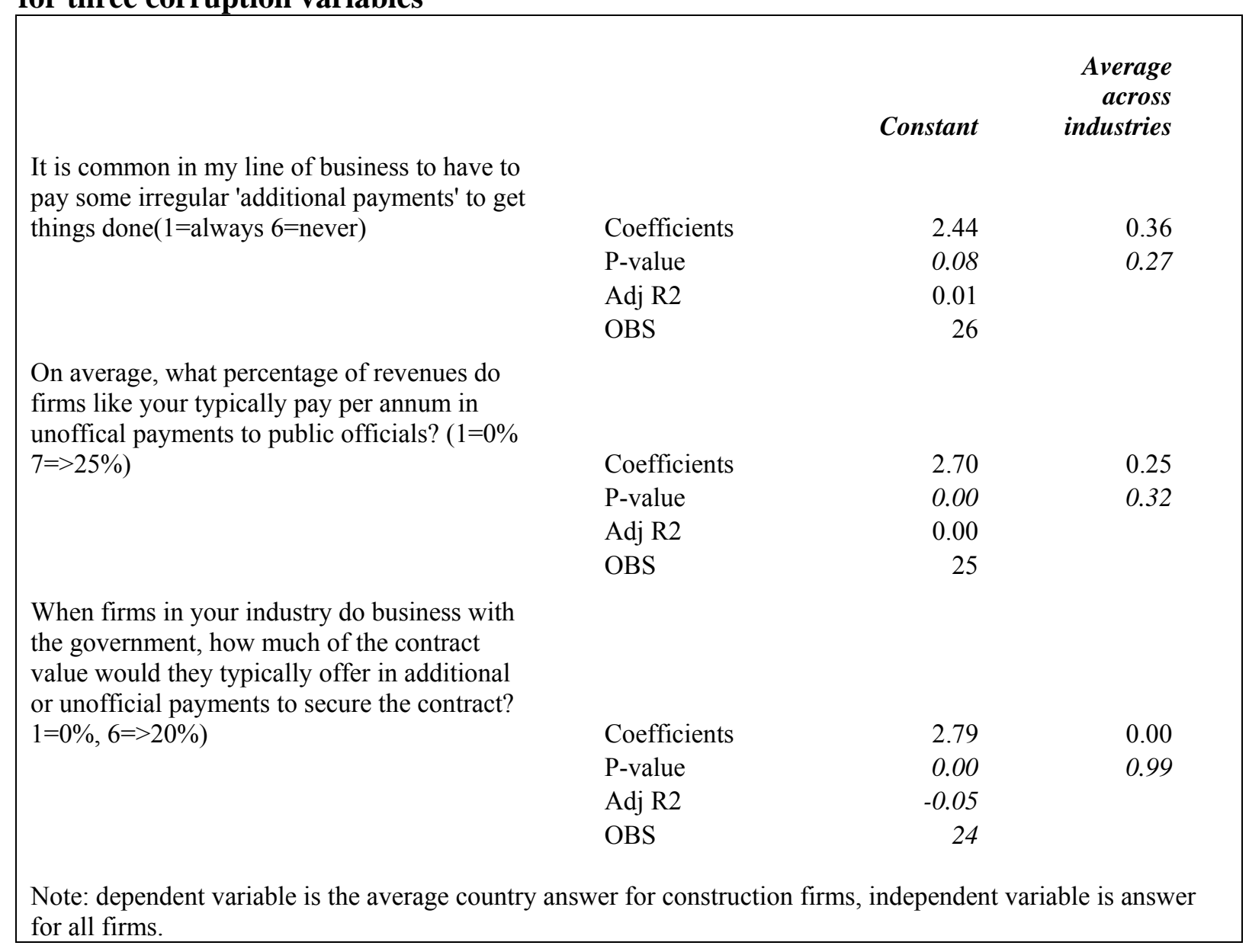


Table 3: Zimbabwe, Corruption and New Stories

\begin{tabular}{|lrrr|}
\hline News Stories That Mention... & Africa & Zimbabwe \\
Which also mention... & & \\
Corruption (\%) & $1996-2000$ & 2.3 & 3.5 \\
& $2000-2004$ & 3.1 & 4.8 \\
Crime (\%) & $1996-2000$ & 3.1 & 1.9 \\
& $2000-2004$ & 3.4 & 3.2 \\
Crisis (\%) & $1996-2000$ & 6.1 & 6.5 \\
\multicolumn{4}{l}{ Search from Factiva, 08/30/06, covering stories in 'major news' outlets as defined by } \\
Factiva: "Sources covering general news and business news that are considered key \\
publications in their region by virtue of circulation or reputation." Total number of \\
stories: Africa 1996-2000 304,495 2000-2004 419,855; Zimbabwe 1996-200 34,917 \\
2000-2004 71,265.
\end{tabular}


Table 4: BEEPS and Transparency International CPI

\begin{tabular}{|c|c|c|c|}
\hline & Constant & $\begin{array}{l}\text { Independent } \\
\text { variable }\end{array}$ & $\begin{array}{l}\text { Adjusted } \\
\text { R2 }\end{array}$ \\
\hline $\begin{array}{l}\text { DV: How often do firms like yours need to make extra, unofficial } \\
\text { payments to gain government contracts? }(1=\text { always } 6=\text { never }) \\
\text { IV: Transparency International Ranking } \\
\text { Sample: country averages ( } 26 \mathrm{Obs})\end{array}$ & $5.55^{*}$ & $-0.005 * *$ & 0.17 \\
\hline $\begin{array}{l}\text { DV: How often do firms like yours need to make extra, unofficial } \\
\text { payments to get licences and permits? }(1=\text { always } 6=\text { never }) \\
\text { IV: Transparency International Ranking } \\
\text { Sample: country averages ( } 26 \text { Obs) }\end{array}$ & $5.45 *$ & $-0.006^{*}$ & 0.32 \\
\hline $\begin{array}{l}\text { DV: How often do firms like yours need to make extra, unofficial } \\
\text { payments to gain government contracts? ( } 1=\text { always } 6=\text { never }) \\
\text { IV: How often do firms like yours need to make extra, unofficial } \\
\text { payments to deal with taxes and tax collection? (1=always } 6=\text { never) } \\
\text { Sample: construction firms ( } 322 \text { Obs) }\end{array}$ & $2.91 *$ & $0.46^{*}$ & 0.35 \\
\hline $\begin{array}{l}\text { DV: How often do firms like yours need to make extra, unofficial } \\
\text { payments to gain government contracts? }(1=\text { always } 6=\text { never }) \\
\text { IV: Transparency International Ranking } \\
\text { Sample: construction firm country averages ( } 26 \mathrm{Obs})\end{array}$ & 4.30 & 0.005 & 0.00 \\
\hline
\end{tabular}


Table 5: Investment Climate Questions on Contract Corruption: Correlations

\begin{tabular}{|c|c|c|c|}
\hline & Constant & $\begin{array}{l}\text { Independent } \\
\text { variable }\end{array}$ & $\begin{array}{l}\text { Adjusted } \\
\text { R2 }\end{array}$ \\
\hline $\begin{array}{l}\text { DV: Value of gift expected to secure government contract (\% contract } \\
\text { value) } \\
\text { IV: Transparency International CPI } \\
\text { Sample: country averages }(51 \mathrm{Obs})\end{array}$ & $3.41 *$ & -0.30 & 0.00 \\
\hline $\begin{array}{l}\text { DV: Value of gift expected to secure government contract (\% contract } \\
\text { value) } \\
\text { IV: \% managers ranking corruption as a major constraint to doing business } \\
\text { Sample: country averages ( } 44 \mathrm{Obs})\end{array}$ & -0.11 & $0.08 *$ & 0.34 \\
\hline $\begin{array}{l}\text { DV: Value of gift expected to secure government contract (\% contract } \\
\text { value) } \\
\text { IV: GDP per capita }(\log ) \\
\text { Sample: country averages }(50 \mathrm{Obs})\end{array}$ & $6.65 * * *$ & -0.50 & 0.01 \\
\hline $\begin{array}{l}\text { DV: Transparency International CPI } \\
\text { IV: GDP per capita }(\log ) \\
\text { Sample: country averages }(50 \mathrm{Obs})\end{array}$ & $-3.04 *$ & $0.74^{*}$ & 0.42 \\
\hline $\begin{array}{l}\text { DV: \% managers ranking corruption as a major constraint to doing } \\
\text { business } \\
\text { IV: GDP per capita (log) } \\
\text { Sample: country averages ( } 43 \mathrm{Obs})\end{array}$ & $131 *$ & $-11.6^{*}$ & 0.25 \\
\hline $\begin{array}{l}\text { DV: \% managers ranking corruption as a major constraint to doing } \\
\text { business } \\
\text { IV: Transparency International CPI } \\
\text { Sample: country averages ( } 48 \mathrm{Obs)}\end{array}$ & $58.9 *$ & $-8.42 *$ & 0.17 \\
\hline
\end{tabular}


Table 6: Investment Climate Questions on Electrical Connection Corruption: Correlations

\begin{tabular}{|c|c|c|c|}
\hline & Constant & $\begin{array}{l}\text { Independent } \\
\text { variable }\end{array}$ & $\begin{array}{l}\text { Adjusted } \\
\text { R2 }\end{array}$ \\
\hline $\begin{array}{l}\text { DV: \% Firms expected to give gift to get an electrical connection } \\
\text { IV: Value of gift to get a government contract }(\%) \\
\text { Sample: country averages ( } 20 \text { Obs) }\end{array}$ & $14.2 *$ & 0.1 & -0.05 \\
\hline $\begin{array}{l}\text { DV: \% Firms expected to give gift to get an electrical connection } \\
\text { IV: \% Firms expected to give gift to get a telephone connection } \\
\text { Sample: country averages ( } 21 \text { Obs) }\end{array}$ & $5.36 * * *$ & $0.71 *$ & 0.71 \\
\hline $\begin{array}{l}\text { DV: \% Firms expected to give gift to get an electrical connection } \\
\text { IV: \% Firms expected to give gift to get a water connection } \\
\text { Sample: country averages ( } 15 \text { Obs) }\end{array}$ & $4.88 * * *$ & $0.84^{*}$ & 0.64 \\
\hline $\begin{array}{l}\text { DV: \% Firms expected to give gift to get an electrical connection } \\
\text { IV: \% Firms expected to give gift to get a construction permit } \\
\text { Sample: country averages ( } 17 \text { Obs) }\end{array}$ & 0.26 & $0.91 *$ & 0.76 \\
\hline $\begin{array}{l}\text { DV: \% Firms expected to give gift to get an electrical connection } \\
\text { IV: Transparency International CPI } \\
\text { Sample: country averages ( } 21 \mathrm{Obs})\end{array}$ & 22 & -1.56 & -0.04 \\
\hline $\begin{array}{l}\text { DV: \% Firms expected to give gift to get an electrical connection } \\
\text { IV: \% Managers ranking corruption as a major barrier } \\
\text { Sample: country averages ( } 13 \text { Obs) }\end{array}$ & 2.86 & 0.14 & 0.07 \\
\hline
\end{tabular}


Table 7: Investment Climate Questions on Infrastructure Corruption: Correlations

\begin{tabular}{|c|c|c|c|c|c|}
\hline & Constant & $\begin{array}{l}\text { Log GDP per } \\
\text { Capita }\end{array}$ & Corruption & Adjusted R2 & $\mathbf{N}$ \\
\hline $\begin{array}{l}\text { DV: } \log \text { mobile phones } / 1,000 \\
\text { IV: firms expected to give gifts to get } \\
\text { a phone connection }\end{array}$ & $-3.16 * *$ & $1.00 *$ & -0.00 & 0.72 & 21 \\
\hline $\begin{array}{l}\text { DV: waiting list for telephone } \\
\text { mainlines } \\
\text { IV: firms expected to give gifts to get } \\
\text { a phone connection }\end{array}$ & -1.52 & 0.18 & $0.02 *$ & 0.61 & 11 \\
\hline $\begin{array}{l}\text { DV: \% population with access to } \\
\text { improved water source } \\
\text { IV: firms expected to give gifts to get } \\
\text { a water connection }\end{array}$ & -7.32 & $11.4 * *$ & -0.34 & 0.51 & 15 \\
\hline $\begin{array}{l}\text { DV: \% managers who rank electricity } \\
\text { as a major constraint to doing } \\
\text { business } \\
\text { IV: firms expected to give gifts to get } \\
\text { an electricity connection }\end{array}$ & $123 *$ & $-12.0 * *$ & 0.32 & 0.77 & 13 \\
\hline $\begin{array}{l}\text { DV: \% of roads paved } \\
\text { IV: Value of gift expected to secure } \\
\text { government contract }\end{array}$ & 1.28 & $0.34 * *$ & $-0.16^{*}$ & 0.44 & 33 \\
\hline
\end{tabular}


Table 8: Corruption in BEEPS: How are Construction Firms Different?

\begin{tabular}{|c|c|c|c|c|c|}
\hline & $\begin{array}{l}\text { Average } \\
\text { Construction }\end{array}$ & Average All & $\begin{array}{l}\text { Construction } \\
<\text { All\% }\end{array}$ & $\begin{array}{l}\text { Construction } \\
\text { Coeff }\end{array}$ & $\begin{array}{l}\text { Construction } \\
\text { Prob }\end{array}$ \\
\hline $\begin{array}{l}\text { It is common in my line of business to have to pay some irregular } \\
\text { 'additional payments' to get things done }\end{array}$ & 3.9 & 4.2 & 0.69 & -0.39 & 0.00 \\
\hline $\begin{array}{l}\text { On average, what percentage of revenues do firms like yours pay in } \\
\text { unofficial payments? }(1=0,7=\text { over } 25 \%)\end{array}$ & 3.5 & 3.2 & 0.38 & 0.29 & 0.00 \\
\hline $\begin{array}{l}\text { How often do firms like yours need to make extra, unofficial payments to } \\
\text { get connected to public services? ( } 1=\text { always } 6=\text { never })\end{array}$ & 5.2 & 5.2 & 0.42 & -0.09 & 0.24 \\
\hline $\begin{array}{l}\text { How often do firms like yours need to make extra, unofficial payments to } \\
\text { get licences and permits? }(1=\text { always } 6=\text { never })\end{array}$ & 4.8 & 5.0 & 0.46 & -0.19 & 0.02 \\
\hline $\begin{array}{l}\text { How often do firms like yours need to make extra, unofficial payments to } \\
\text { deal with taxes and tax collection? ( } 1=\text { always } 6=\text { never })\end{array}$ & 5.1 & 5.1 & 0.50 & -0.13 & 0.09 \\
\hline $\begin{array}{l}\text { How often do firms like yours need to make extra, unofficial payments to } \\
\text { gain government contracts? }(1=\text { always } 6=\text { never })\end{array}$ & 4.7 & 5.1 & 0.77 & -0.56 & 0.00 \\
\hline $\begin{array}{l}\text { How often do firms like yours need to make extra, unofficial payments } \\
\text { when dealing with customs/imports? }(1=\text { always } 6=\text { never })\end{array}$ & 5.2 & 5.1 & 0.38 & 0.01 & 0.91 \\
\hline $\begin{array}{l}\text { How often do firms like yours need to make extra, unofficial payments } \\
\text { when dealing with courts? }(1=\text { always } 6=\text { never }) \\
\text { How often do firms like yours need to make extra, unofficial payments to } \\
\text { influence the content of new laws, decrees or regulations? ( } 1=\text { always }\end{array}$ & 5.2 & 5.2 & 0.58 & -0.07 & 0.34 \\
\hline $6=$ never) & 5.7 & 5.6 & 0.46 & -0.04 & 0.46 \\
\hline $\begin{array}{l}\text { Of total unofficial payments that a firm like yours would make in any } \\
\text { given year, what percentage to gain government contracts? }(\%) \\
\text { When firms in your industry do business with the government, how much } \\
\text { of the contract value would they typically offer in additional or unofficial } \\
\text { payments to secure the contract? }(1=0 \%, 6>25 \%)\end{array}$ & 23.0 & 15.4 & 0.20 & 11.92 & 0.00 \\
\hline
\end{tabular}


Table 9: All firms in BEEPS: What Determines Corrupt Payments?

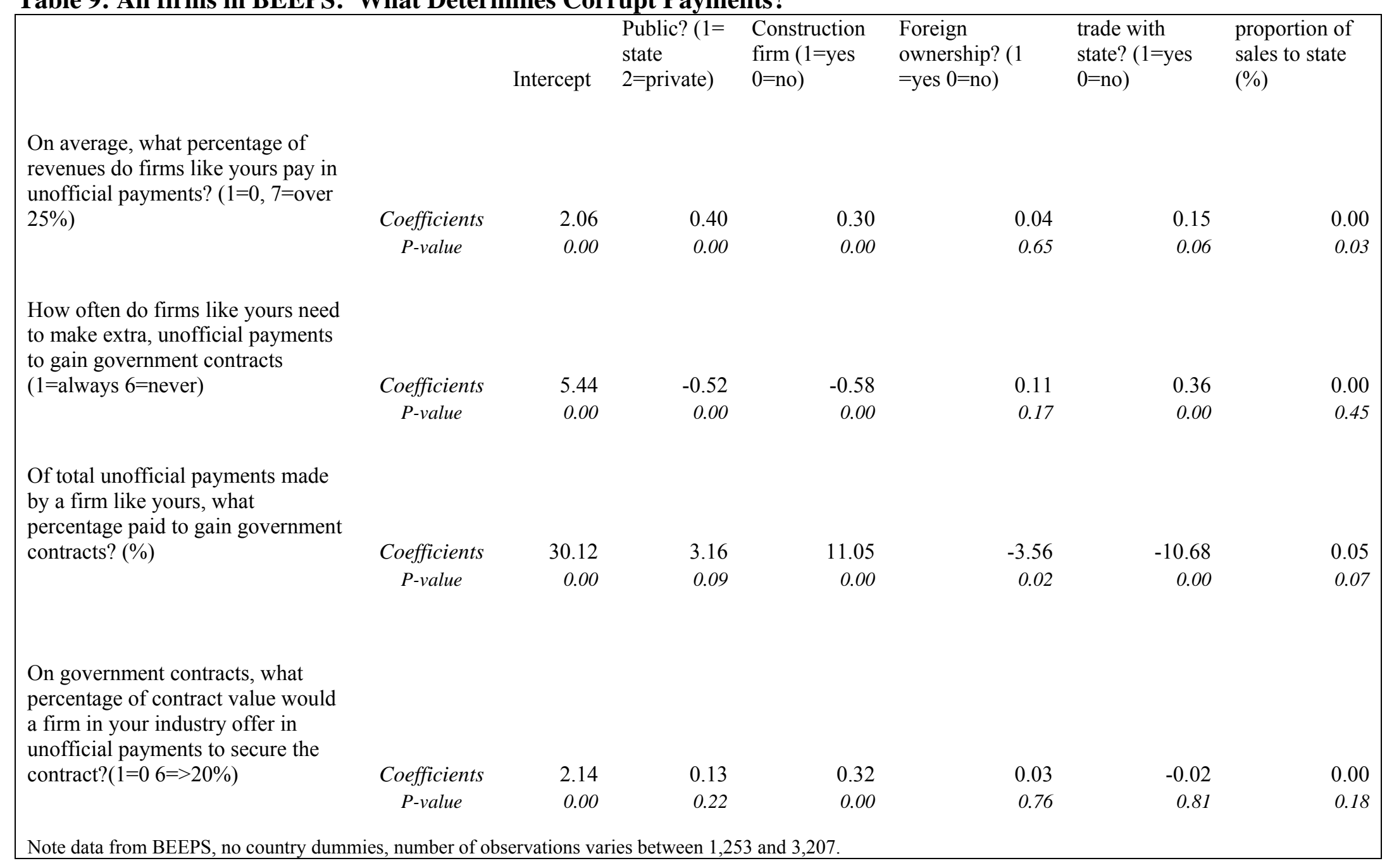


Table 10: Construction Firms in BEEPS: When Firms in your industry do business with the government, how much of the contract value would they typically offer in additional or unofficial payments to secure the contract? $(1=0,6>20 \%)$ Significance of country dummies

\begin{tabular}{|c|c|c|c|c|c|c|}
\hline & \multicolumn{2}{|l|}{ All Firms } & \multicolumn{2}{|l|}{ Private Firms } & \multicolumn{2}{|c|}{ Private which Trade with Gov't } \\
\hline & Coefficients & $P$-value & Coefficients & P-value & Coefficients & P-value \\
\hline Intercept & 2.91 & 0.00 & 3.00 & 0.00 & 3.00 & 0.00 \\
\hline Azerbaijan & 0.71 & 0.08 & 0.33 & 0.51 & & \\
\hline Czech Republic & 0.09 & 0.83 & 0.00 & 1.00 & 0.43 & 0.61 \\
\hline Estonia & -0.51 & 0.19 & -0.69 & 0.09 & -0.67 & 0.41 \\
\hline Poland & -0.64 & 0.13 & -0.73 & 0.09 & -0.88 & 0.29 \\
\hline Russia & -0.48 & 0.15 & -0.52 & 0.15 & -0.52 & 0.49 \\
\hline Slovakia & & & & & -1.00 & 0.29 \\
\hline Turkey & -0.11 & 0.77 & -0.26 & 0.49 & -0.13 & 0.87 \\
\hline Ukraine & -0.24 & 0.53 & -0.21 & 0.60 & -0.10 & 0.90 \\
\hline Uzbekistan & -0.69 & 0.08 & -0.70 & 0.11 & -0.67 & 0.41 \\
\hline \multirow[t]{3}{*}{ (Slovakia Excluded) } & & & (Slovakia Excluded) & & (Azerbaijan Exclu & \\
\hline & Adj R2 & 0.09 & Adj R2 & 0.02 & Adj R2 & 0.02 \\
\hline & Observations & 143 & Observations & 125 & Observations & 87 \\
\hline
\end{tabular}


Table 11: Construction firms in BEEPS: How often do firms like yours nowadays need to make extra, unofficial payments to public officials to gain government contracts? $1=$ Always $6=$ Never, Significance of Country Dummies

\begin{tabular}{|c|c|c|c|c|c|c|}
\hline & \multirow{2}{*}{$\begin{array}{l}\text { Full Sample } \\
\text { Coefficients }\end{array}$} & \multicolumn{3}{|c|}{ Excluding Never (6) } & \multicolumn{2}{|c|}{$\begin{array}{l}\text { Dummy (never }=0 \text { always- } \\
\text { seldom }=1 \text { ) }\end{array}$} \\
\hline & & P-value & Coefficients & P-value & Coefficients & $P$-value \\
\hline Intercept & 5.32 & 0.00 & 5.00 & 0.00 & 0.27 & 0.01 \\
\hline Azerbaijan & -1.15 & 0.01 & -1.75 & 0.23 & 0.39 & 0.00 \\
\hline Estonia & -0.47 & 0.31 & -1.38 & 0.35 & 0.21 & 0.12 \\
\hline Georgia & -0.07 & 0.88 & -1.00 & 0.50 & 0.10 & 0.46 \\
\hline Hungary & 0.63 & 0.20 & & & -0.22 & 0.13 \\
\hline Kyrgyzstan & & & -1.50 & 0.33 & & \\
\hline Latvia & -0.20 & 0.67 & -1.44 & 0.33 & 0.09 & 0.53 \\
\hline Poland & -0.23 & 0.60 & -1.73 & 0.24 & 0.06 & 0.64 \\
\hline Russia & -0.37 & 0.34 & -1.93 & 0.18 & 0.08 & 0.46 \\
\hline Turkey & -1.57 & 0.00 & -2.24 & 0.12 & 0.42 & 0.00 \\
\hline Ukraine & -0.52 & 0.22 & -2.69 & 0.07 & 0.05 & 0.68 \\
\hline \multirow[t]{5}{*}{ Uzbekistan } & -0.28 & 0.54 & -1.50 & 0.31 & 0.11 & 0.41 \\
\hline & \multicolumn{2}{|c|}{ Kyrgyzstan excluded } & \multicolumn{2}{|c|}{ Hungary Excluded } & \multicolumn{2}{|c|}{ Kyrgyzstan excluded } \\
\hline & \multicolumn{2}{|c|}{ Regression Statistics } & \multicolumn{2}{|c|}{ Regression Statistics } & \multicolumn{2}{|c|}{ Regression Statistics } \\
\hline & Adjusted R2 & 0.07 & Adjusted R2 & 0.03 & Adjusted R2 & 0.07 \\
\hline & Observations & 361 & Observations & 143 & Observations & 361 \\
\hline
\end{tabular}


Table 12: Approaches to Measuring the Development Impact of Weak Governance and Corruption in Infrastructure

\section{Overall Budgeting}

Are general budget priorities correct?

Are resources reaching targeted activities?

\section{Investment Cycle}

Are good projects selected?

Are projects well executed?

\section{Licensing and Regulation}

Are licenses issued correctly, fairly

Are standards met?

Operation

Are facilities well

operated/maintained?
Benchmark analysis of budgeting priorities -O\&M versus new investment

Public expenditure tracking surveys

Economic and technical analysis of representative set of sector investments. Analysis of legal/political process of selection, interviews with key officials

Physical and financial audit of representative sample of recent projects, cost benchmarking, survey of intended beneficiaries, interviews with key officials, contractors, losing bidders

Economic and technical analysis of process, interviews with key officials, industry associations, company surveys

User surveys, interviews with licensee staff, physical audits.

User surveys, interviews with key staff, physical audits. 
Figure One: Average and Standard Deviation Across Countries of Frequency of Bribes for Connection to Public Services (1=Always, 6=Never)

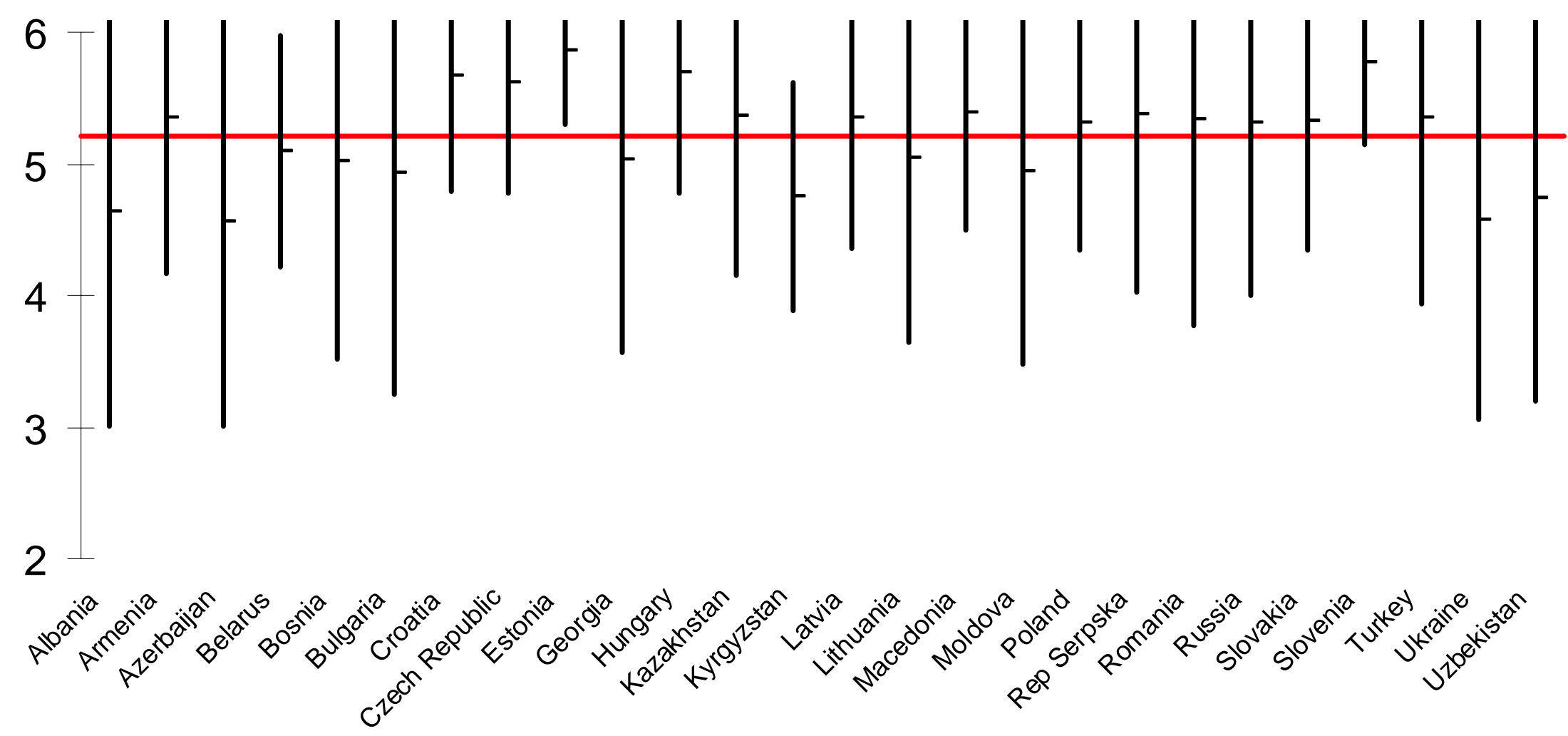


Figure Two: Two Measures of Bribes to Government Contracts as a Percentage of Revenues

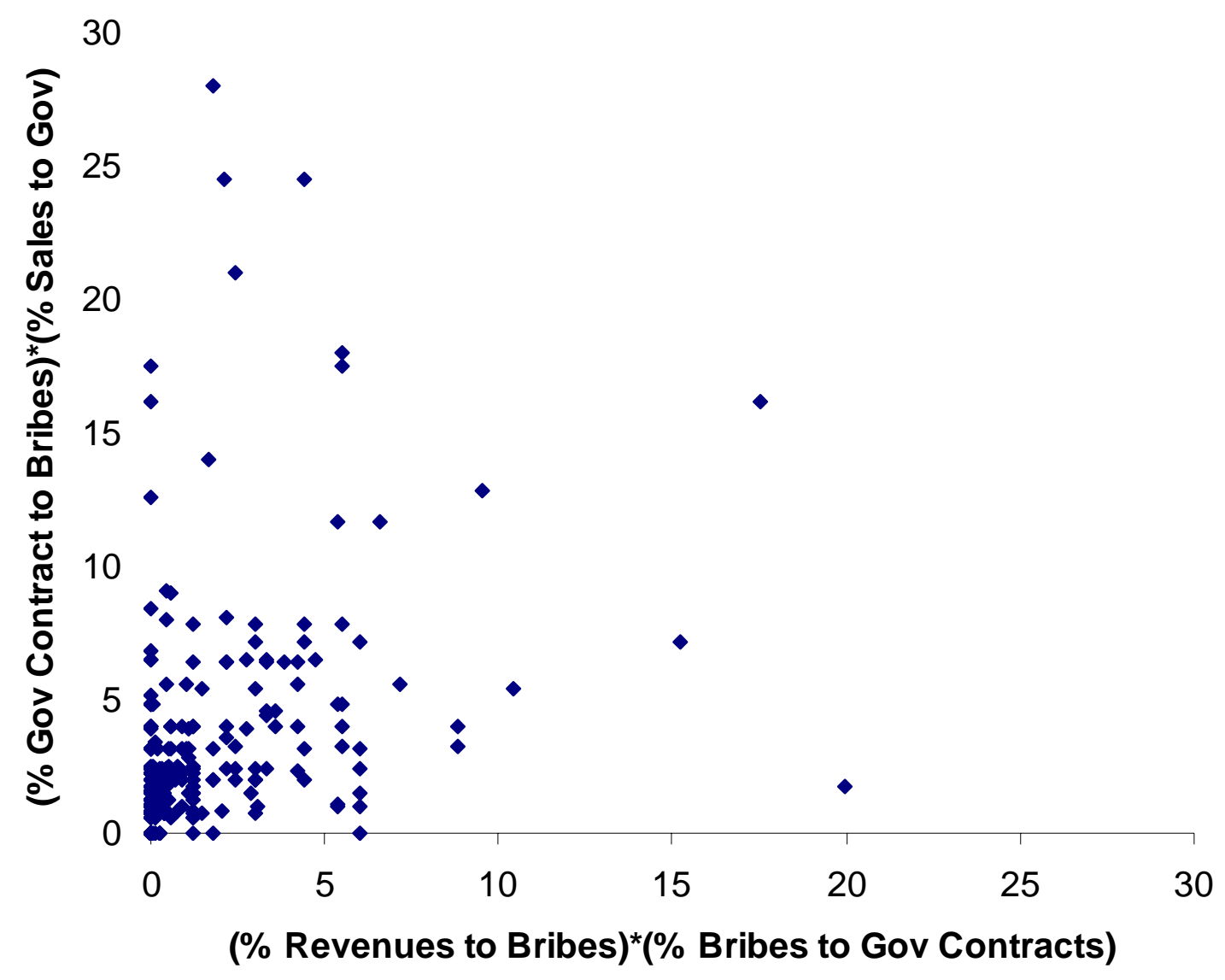


Figure Three: Two Measures of Bribes to Government Contracts as a Percentage of Revenues (Ranges)

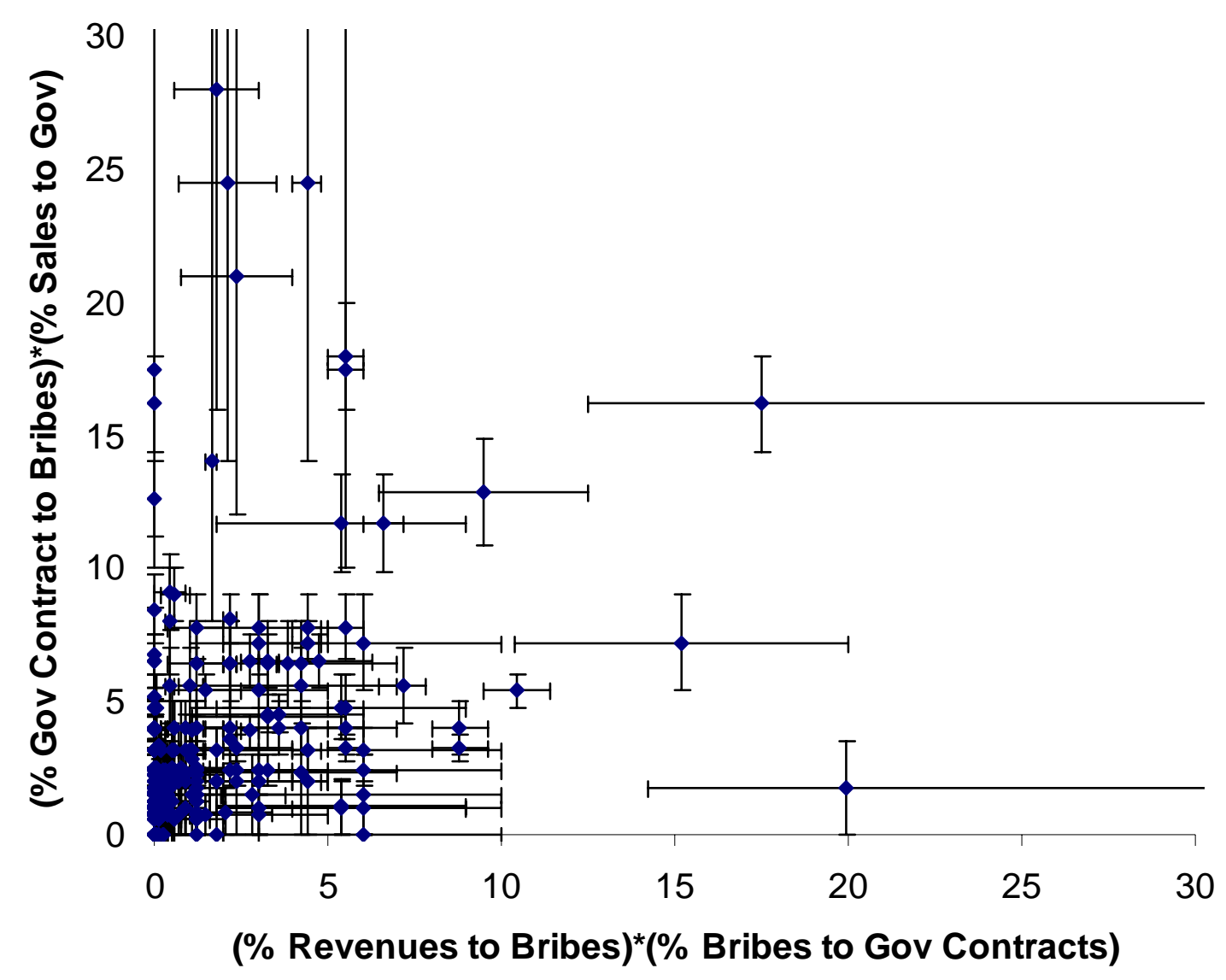


Figure Four: Average and Standard Deviation Across Countries of Construction Company Contract Bribes of Government Contracts

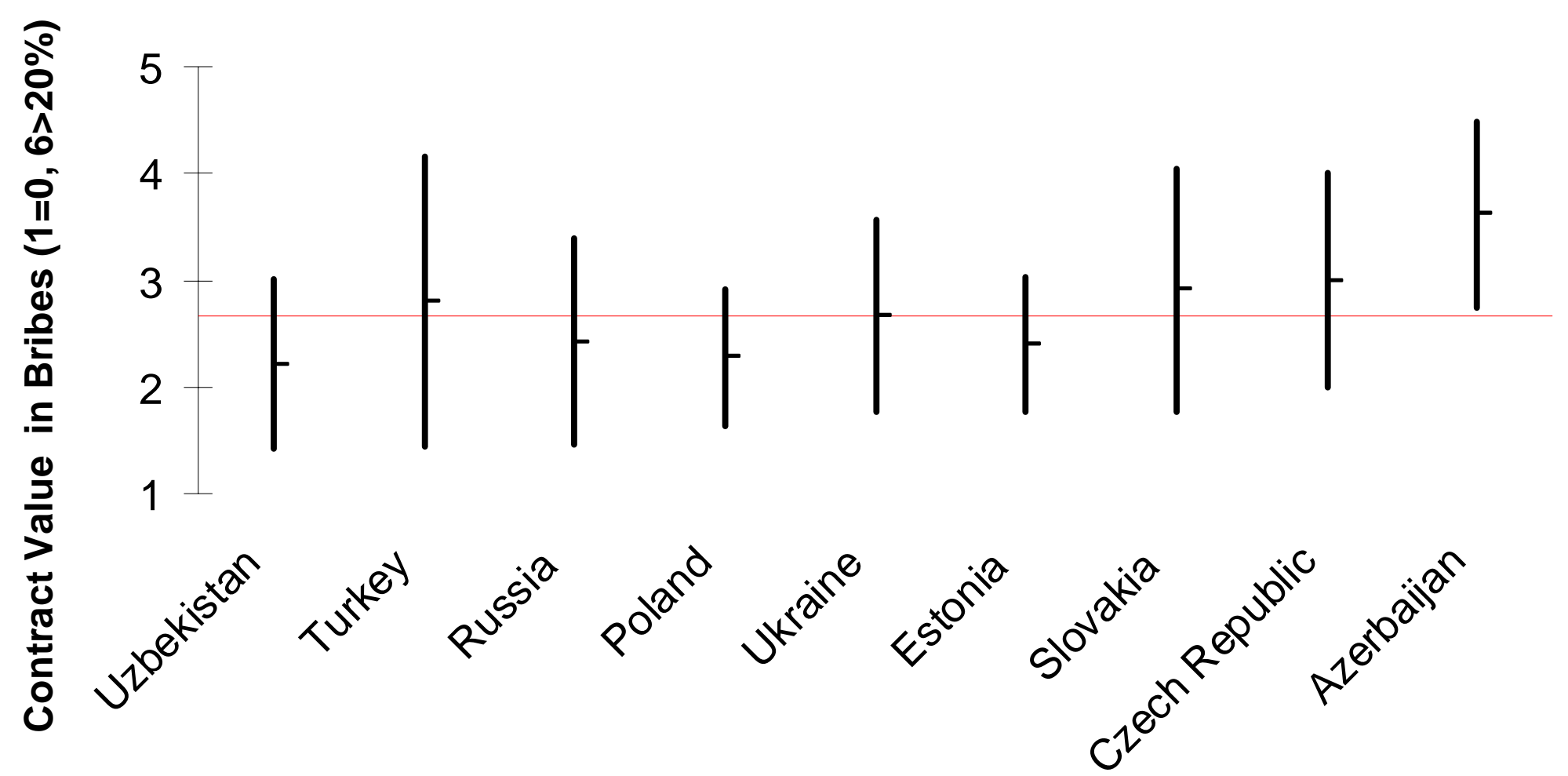

Notes: $\mathrm{X}$-axis crosses at average value for answer, chart displays average and standard deviation for each country, see Table 12 for additional notes. 
Figure Five: More and Less Harmful Bribes

\begin{tabular}{|c|c|c|}
\hline \multirow[t]{2}{*}{$\begin{array}{l}\text { Bribe Paid On the } \\
\text { Basis of... }\end{array}$} & \multicolumn{2}{|c|}{$\begin{array}{l}\text { Status of Act Performed/Not Performed in } \\
\text { Return for Bribe }\end{array}$} \\
\hline & Legal/encouraged & Illegal/discouraged \\
\hline $\begin{array}{l}\text { Commission } \\
\text { (Action) }\end{array}$ & $\begin{array}{l}\text { Speed payment for } \\
\text { legal connection }\end{array}$ & $\begin{array}{l}\text { Contract award to } \\
\text { (paying) non- } \\
\text { competitive bidder, } \\
\text { illegal connection }\end{array}$ \\
\hline $\begin{array}{l}\text { Omission } \\
\text { (Inaction) }\end{array}$ & $\begin{array}{l}\text { Enforcement of } \\
\text { regulation, bill } \\
\text { collection, quality } \\
\text { standard }\end{array}$ & $\begin{array}{l}\text { Contract award to } \\
\text { (other) non- } \\
\text { competitive bidder, } \\
\text { disconnection of } \\
\text { legal service }\end{array}$ \\
\hline
\end{tabular}

